\title{
Article
}

\section{How to Harvest Haylage Bales in Sustainable Agriculture}

\author{
Sylwester Borowski * (D), Jerzy Kaszkowiak and Edmund Dulcet
}

Faculty of Mechanical Engineering, University of Science and Technology, Al. Prof. S. Kaliskiego 7, 85-796 Bydgoszcz, Poland; kaszk@pbs.edu.pl (J.K.); dulcet@pbs.edu.pl (E.D.)

* Correspondence: sylwester.borowski@pbs.edu.pl

Citation: Borowski, S.; Kaszkowiak, J.; Dulcet, E. How to Harvest Haylage Bales in Sustainable Agriculture. Appl. Sci. 2021, 11, 11508. https:// doi.org/10.3390/app112311508

Academic Editor: Claudio De Pasquale

Received: 5 November 2021

Accepted: 2 December 2021

Published: 4 December 2021

Publisher's Note: MDPI stays neutral with regard to jurisdictional claims in published maps and institutional affiliations.

Copyright: (c) 2021 by the authors. Licensee MDPI, Basel, Switzerland. This article is an open access article distributed under the terms and conditions of the Creative Commons Attribution (CC BY) license (https:// creativecommons.org/licenses/by/ $4.0 /)$.

\begin{abstract}
Storing silage in round bales (balage) is a commonly used method for preserving forage for use as stock fodder that has a higher nutritional content than hay. Baling at the optimum density is important for ensuring ideal fermentation conditions. In the manuscript, we present the research methodology and the results of the experiment. We did experiments over the density of haylage bales. We investigated the effect of the moisture content in the harvested material, the length of the cut material and the pressing pressure in the round baler. We used the Barenbrug BG- 5 forage mix at different moisture content levels $(69,63,56,49$, and $42 \%)$, that was either unchopped or chopped by the round baler's cutter bars (312 and $183 \mathrm{~mm}$ length) and baled at three different pressing pressures $(0.9,1.4$, and 1.8 MPa). The results showed that forage density in the bales reached the highest value at a moisture content of $56 \%$ and a pressing pressure of $1.8 \mathrm{MPa}$, with the forage chopped by the cutter bars.
\end{abstract}

Keywords: additives; dosing of additives; sustainable agriculture; haylage; precision agriculture

\section{Introduction}

The terms silage and haylage are often confused and used interchangeably. The correct definition is essential here so that there are no mistakes in the interpretation of our research. Silage is defined as "material produced by the controlled fermentation of a yield with a high moisture content" [1]. Haylage has been defined as wrapped or anaerobically stored feed containing $>500 \mathrm{~g}$ dry matter per $\mathrm{kg}[2,3]$.

Storing silage in round bales (balage or haylage) is a commonly used method for preserving forage for use as stock fodder that has a higher nutritional content than hay. The density of plant material in bales formed with round balers is an important indicator of these machines' operating quality. In the case of the balage itself, good density ensures advantageous conditions for fermentation [4-6]. Data presented in the literature indicate that the moisture content of the plant material has a big impact on the compacting process. Humid blades or stalks bend much more easily than dry ones. Particular attention should be given to data concerning the compaction of bales formed from green fodder with a dry mass content of $\sim 63$ to $64 \%$. Material of this type, which has a low elasticity, is easily pressed into the working chamber of a round baler, which results in a high concentration within the cylindrical bales [7-11]. The inclusion of shredding assemblies within round balers results in an increase in the concentration of the resulting bales by several percent, which, in some cases, can be even more than $20 \%[6,12,13]$.

At present, the production of feed with the use of different additives to support the silaging process is very popular, ensuring that farmers have supplies of cheap yet valuable feed with low nutrients losses that is suitable for long-term storage [5,14-19]. Liquid additives are applied to the plant material by applicators fitted to the baling machines. Applicator nozzles are mounted on the baling machines at points that allow for optimum distribution of additives in the collected plant material and low additive losses [19-21].

The aim of the experiment was to study the influence of: moisture content in the har-vested material, length of the cut material and the pressing pressure in the baler on 
the obtained density of haylage bales. Haylage bales were made of grass Barenbrug BG5 forage mixtures (B\&G-4 Milkway Universal, Barenbrug Poland, Tarnowo Podgórne, Poland) with the addition of a liquid additive.

\section{Materials and Methods}

Our experiment included the following independent variables: moisture content of the plant material $\left(\mathrm{M}_{\mathrm{C}}\right)$, length of plant material $\left(\mathrm{L}_{\mathrm{m}}\right)$, and pressing pressure $\left(\mathrm{P}_{\mathrm{P}}\right)$. Compaction of the plant material in bales (volumetric mass of the pressed material) was assumed to be the dependent variable. A diagram of the study design is presented in Figure 1. The levels and values of the independent variables $\left(\mathrm{M}_{\mathrm{C}}, \mathrm{L}_{\mathrm{m}}\right.$, and $\left.\mathrm{P}_{\mathrm{P}}\right)$ are shown in Table 1.

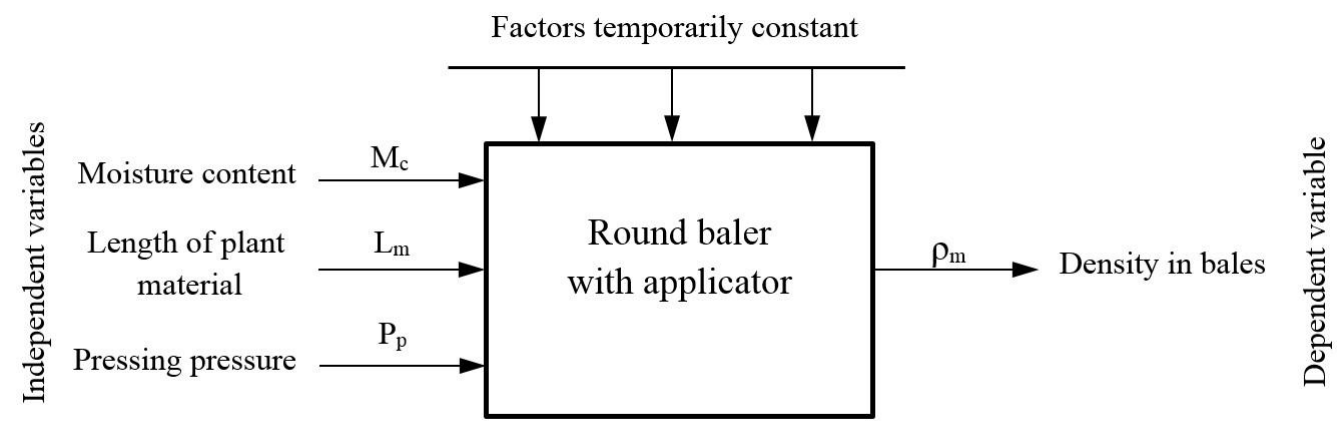

Figure 1. Experimental design.

Table 1. Levels and values of the independent variables.

\begin{tabular}{|c|c|c|c|c|c|c|}
\hline Levels & \multicolumn{5}{|c|}{ Independent Variables } & Unit \\
\hline- & \multicolumn{5}{|c|}{ Moisture content } & - \\
\hline 5 & 69 & 63 & 56 & 49 & 42 & $\%$ \\
\hline- & \multicolumn{5}{|c|}{ Length of plant material } & - \\
\hline 2 & 312 & & & 183 & & $\mathrm{~mm}$ \\
\hline- & \multicolumn{5}{|c|}{ Pressing pressure } & - \\
\hline 3 & 9 & & 14 & \multicolumn{2}{|c|}{18} & $\mathrm{MPa}$ \\
\hline
\end{tabular}

The levels and values of the independent variables have been adopted on the basis of the literature, earlier studies, and the working parameters of the round baler used in the studies.

The experiment was carried out in central Poland, near Nowe Miasto Lubawskie (53.477914 N, $19.395095 \mathrm{~W})$. The plant material used in the studies was the Barenbrug BG-5 forage mix in a hay pasture harvested at the second mowing of the year. The composition of the mix was as follows: timothy (Phleum pratense L.), 25\%; annual ryegrass (Lolium temulentum L.), 20\%; white clover (Trifolium repens L.), 10\%; winter ryegrass (Lolium perenne L.), $20 \%$; red clover (Trifolium pratense L.), $5 \%$. The characteristics of the Barenbrug BG-5 forage mix are presented in Table 2.

Table 2. Characteristics of the Barenbrug BG-5 forage mix.

\begin{tabular}{|c|c|c|c|c|c|}
\hline \multirow{2}{*}{$\begin{array}{c}\text { Moisture } \\
\text { Content } \\
\%\end{array}$} & \multicolumn{2}{|c|}{ Bale } & \multirow{2}{*}{$\begin{array}{c}\text { Average Mass of a } \\
1 \mathrm{~m}^{3} \text { Bale } \\
\mathrm{kg}\end{array}$} & \multicolumn{2}{|c|}{$\begin{array}{l}\text { Average Length } \\
\text { of Plant Material }\end{array}$} \\
\hline & $\begin{array}{l}\text { Width } \\
\text { mm }\end{array}$ & $\begin{array}{l}\text { Height } \\
\text { mm }\end{array}$ & & $\begin{array}{l}\text { Unchopped } \\
\text { mm }\end{array}$ & $\begin{array}{c}\text { Chopped } \\
\text { mm }\end{array}$ \\
\hline 69 & & & 4.10 & & \\
\hline 63 & & & 3.44 & & \\
\hline 56 & 1600 & $230-280$ & 2.89 & 312 & 183 \\
\hline 49 & & & 2.49 & & \\
\hline 42 & & & 2.19 & & \\
\hline
\end{tabular}


Harvest was carried out at the beginning of florescence in June 2015. The weather conditions during the experiment were average insolation, no precipitation, daytime temperatures of 24 to $26^{\circ} \mathrm{C}$ and northeasterly winds of $15 \mathrm{~km} \mathrm{~h}^{-1}$. The grass was mown the day before baling with a disc mower with a swath conditioner (KDT 180, SAMASZ, Zabłudów, Poland). The next day, it was conditioned and the swaths were formed for harvesting with a rotary rake (Z-410, SAMASZ). The forage was baled after obtaining the moisture content required for the experiment.

The additive KemiSile 2000 (Kemira Oyj, Helsinki, Finland; 55\% formic acid, 9\% propionic acid, $24 \%$ ammonium formate, $7 \%$ benzoic acid ester) was used as an additive to control the process of fermentation. This was added at a rate of $3 \mathrm{~L} \mathrm{Mg}^{-1}$ of harvested grass. In the experiment, we added KemiSile to all bales, but we also made control samples without adding any preservative.

The moisture content of the grass mix was determined by drying and weighing. The density of the harvested grass is expressed as the volumetric mass of the pressed material $\left(\mathrm{kg} \mathrm{m}^{-3}\right)$. The change of density in the harvested material was obtained after applying different pressing pressures in the chamber of the round baler (Vicon RF 122 Opticut, Kverneland Group Norvay, Klepp Stasjon, Norway): 0.9, 1.4, and 1.8 MPa.

The forage was harvested and baled at different moisture content levels $(69,63,56,49$, and $42 \%)$. To evaluate the effects of chopping the balage, the forage was either harvested and baled unchopped (312 $\mathrm{mm}$ in length) or baled after being chopped by the round baler's cutter bars (183 mm length).

To ensure that the appropriate dosage of the additive was applied, a sample volume of forage was harvested before the tests, which was then shaken and raked into bales. Before each series of tests, the bales of forage were manually corrected to characterize the uniform distribution of mass along their entire length and width. The moisture content of the forage mix was controlled continually. The additive applicator (Junkkari HP5, JUNKKARI Oy, Ylihärmä, Finland) was adjusted to the capacity required to ensure the proper dosage ( $3 \mathrm{~L} \mathrm{Mg}^{-1}$ of harvested forage) for the calculated volume of plant material. The applicator's nozzle was located in the front part of the round baler's chamber (Figure 2), where losses of the additive were lowest [20].

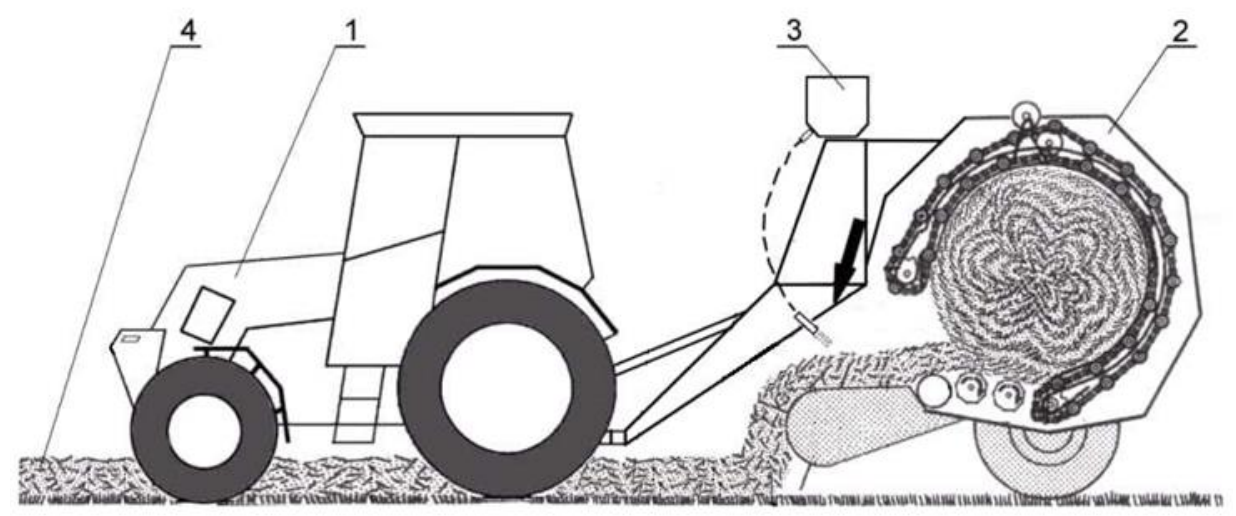

Figure 2. Location of the Junkkari HP 5 applicator spray nozzles on the Vicon RF 122 Opticut round baler. 1 , tractor; 2 , round baler; 3 , applicator; 4 , green forage crop. The arrow shows the applicator spray nozzles located above the press pickup.

To ensure that the tractor was driving at the same speed and that the round baler had the same work efficiency as during harvest, the tractor towing the round baler to which the applicator had been mounted was started up and driven along the bales with forage at a predetermined speed to measure the time of its passage. The bales were wrapped with foil (white 500-mm AgroWrap, Zakład Produkcji Folii Efekt Plus, Warsaw, Poland) three times and then weighted on a suspended scale (AWO 50H, UNIWAG, Kraków, Poland) with a measuring capacity of 0 to $1000 \mathrm{~kg}$ and an accuracy of $1 \mathrm{~kg}$. The volumetric mass 
of the pressed material was calculated from the bales' dimensions ( $1.2 \mathrm{~m}$ wide and $1.2 \mathrm{~m}$ in diameter).

The test results were subjected to ANOVA. The significance of the differences between individual test groups were checked via Tukey's range test. Regressions were carried out with Statistica software (StatSoft Polska Sp., Kraków, Poland).

\section{Results and Discussion}

The average values of plant material density in the bales obtained in the course of the experiment are presented in Table 3.

Table 3. Average values of compaction in $\mathrm{kg}$ dry matter (DM) $\mathrm{m}^{-3}$ in bales for chopped and unchopped plant material at pressing pressures $\left(\mathrm{P}_{\mathrm{P}}\right)$ of 9,14 , and $18 \mathrm{MPa}$.

\begin{tabular}{|c|c|c|c|c|c|c|}
\hline \multirow{4}{*}{$\begin{array}{c}\text { Moisture } \\
\text { Content, } \mathbf{M}_{\mathrm{C}} \\
\%\end{array}$} & \multicolumn{6}{|c|}{ Density of Bales, $\mathrm{kg} \mathrm{DM} \mathrm{m}^{-3}$} \\
\hline & \multicolumn{3}{|c|}{ Unchopped Material (312 mm) } & \multicolumn{3}{|c|}{ Chopped Material (183 mm) } \\
\hline & \multicolumn{6}{|c|}{$\mathbf{P}_{\mathrm{P}}, \mathrm{MPa}$} \\
\hline & 9 & 14 & 18 & 9 & 14 & 18 \\
\hline 69 & 149 & 155 & 163 & 163 & 167 & 174 \\
\hline 63 & 178 & 189 & 196 & 198 & 208 & 216 \\
\hline 56 & 192 & 202 & 211 & 214 & 220 & 233 \\
\hline 49 & 170 & 177 & 190 & 187 & 195 & 209 \\
\hline 42 & 188 & 187 & 193 & 208 & 217 & 222 \\
\hline $56^{a}$ & - & - & 187 & - & - & 205 \\
\hline
\end{tabular}

a Bales without an additive.

The data in Table 3 were used to create bar charts of the density value distribution of the bales, which are presented in Figures 3-11. An analysis of the tests results showed that for both the unchopped $\left(\mathrm{L}_{\mathrm{m}}=312 \mathrm{~mm}\right)$ and the chopped $\left(\mathrm{L}_{\mathrm{m}}=183 \mathrm{~mm}\right)$ material, the density of bales made at $\mathrm{M}_{\mathrm{C}}=69 \%$ was lower than that of other moisture content levels (Figures 3-5: unchopped material; Figures 6-8: chopped material).



Figure 3. Bar chart of balage density in bales at different moisture content levels at a pressing pressure of $18 \mathrm{MPa}$ and plant material at a length of $312 \mathrm{~mm}$. Different lowercase letters indicate a statistically significant difference at $p \leq 0.05$. d.m., dry matter. 


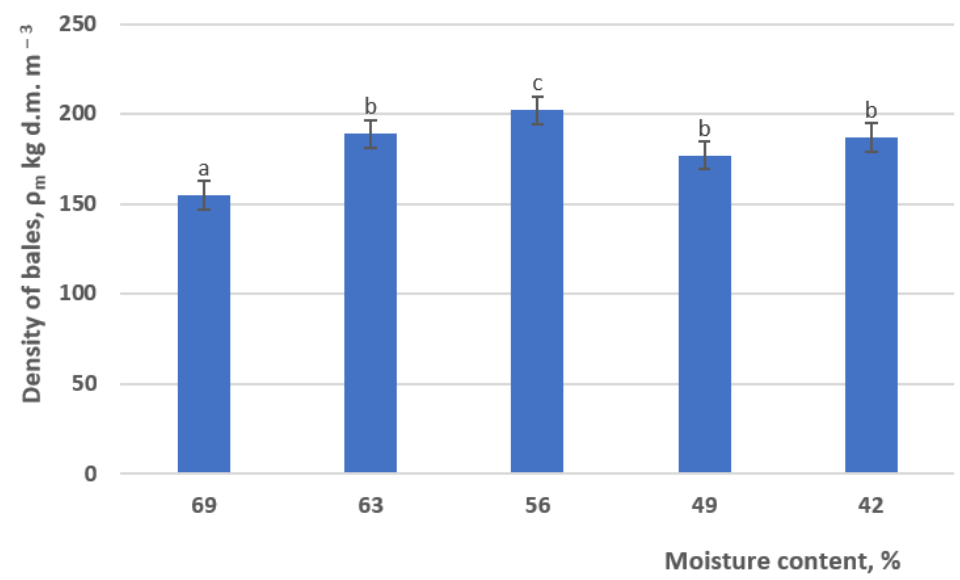

Figure 4. Bar chart of balage density in bales at different moisture content levels at a pressing pressure of $14 \mathrm{MPa}$ and plant material at a length of $312 \mathrm{~mm}$. Different lowercase letters indicate a statistically significant difference at $p \leq 0.05$. d.m., dry matter.

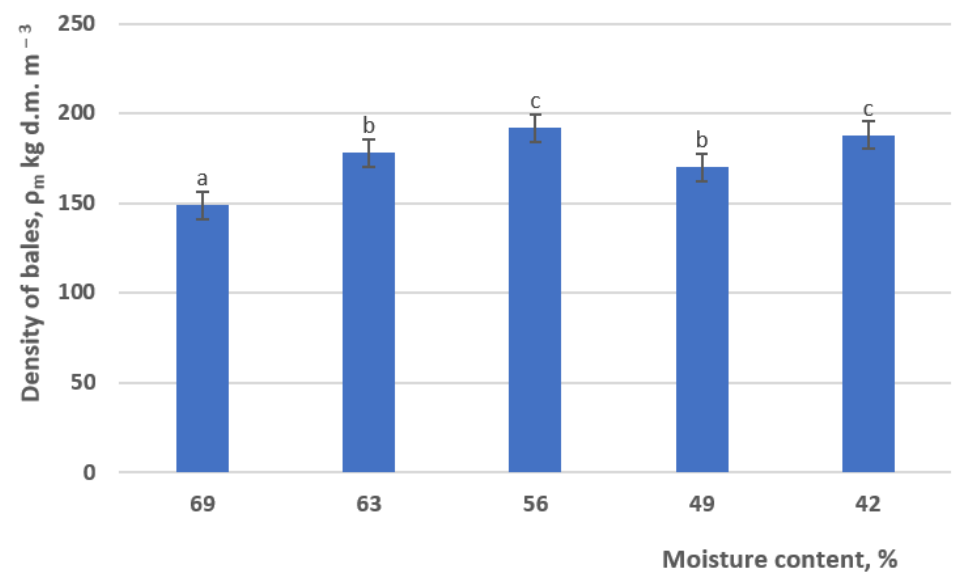

Figure 5. Bar chart of balage density in bales at different moisture content levels at a pressing pressure of $9 \mathrm{MPa}$ and plant material at a length of $312 \mathrm{~mm}$. Different lowercase letters indicate a statistically significant difference at $p \leq 0.05$. d.m., dry matter.

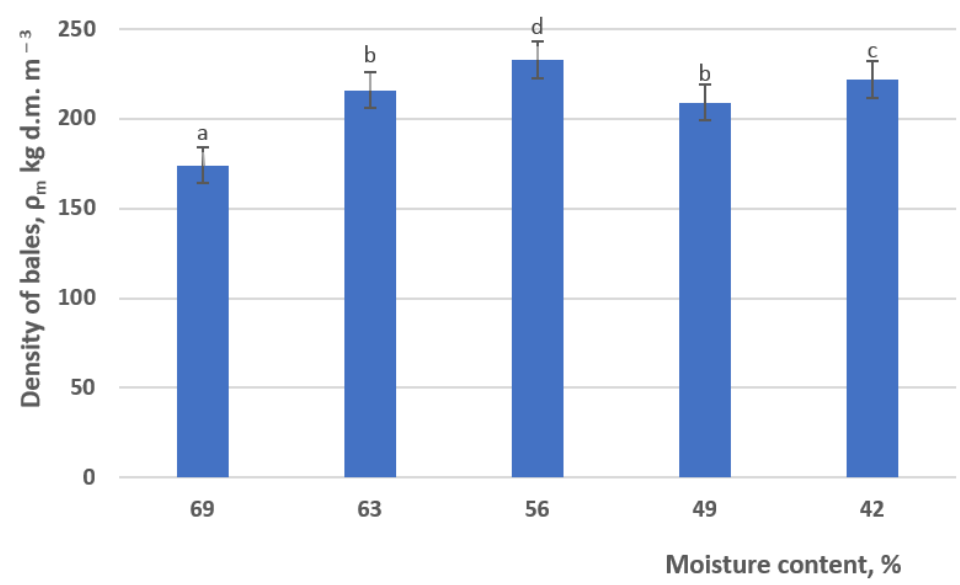

Figure 6. Bar chart of balage density in bales at different moisture content levels at a pressing pressure of $18 \mathrm{MPa}$ and plant material at a length of $183 \mathrm{~mm}$. Different lowercase letters indicate a statistically significant difference at $p \leq 0.05$. d.m., dry matter. 


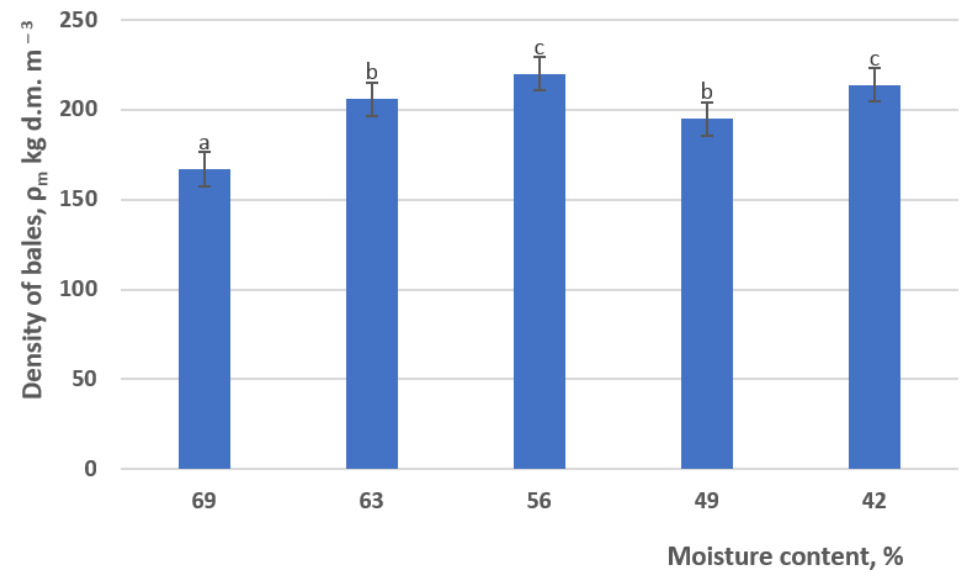

Figure 7. Bar chart of balage density in bales at different moisture content levels at a pressing pressure of $14 \mathrm{MPa}$ and plant material at a length of $183 \mathrm{~mm}$. Different lowercase letters indicate a statistically significant difference at $p \leq 0.05$. d.m., dry matter.

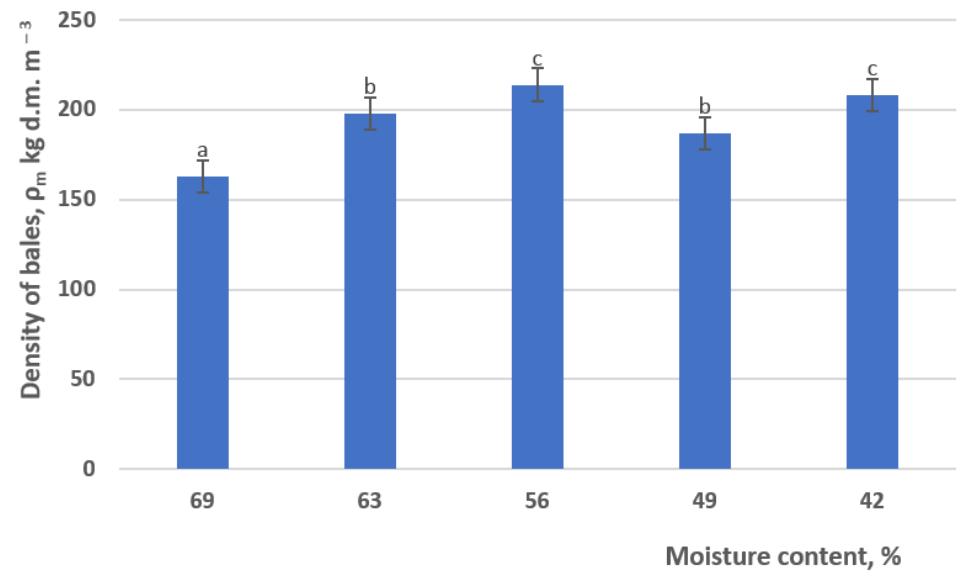

Figure 8. Bar chart of balage density in bales at different moisture content levels at pressing pressure of $9 \mathrm{MPa}$ and plant material at a length of $183 \mathrm{~mm}$. Different lowercase letters indicate a statistically significant difference at $p \leq 0.05$. d.m., dry matter.

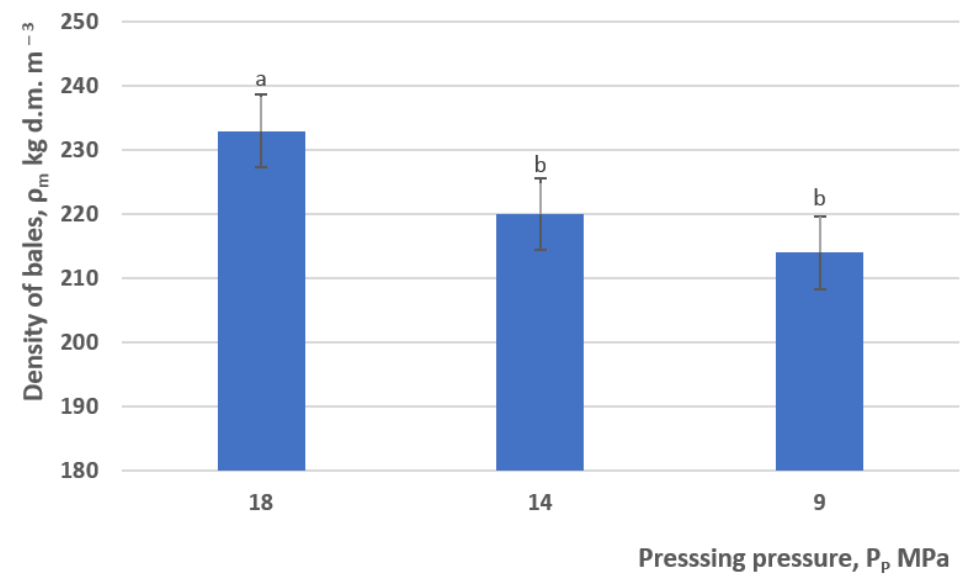

Figure 9. Bar chart of balage density in bales at different pressing pressures (Pp) for plant material at $56 \%$ moisture content and a length Lm of $183 \mathrm{~mm}$. Different lowercase letters indicate a statistically significant difference at $p \leq 0.05$. d.m., dry matter. 


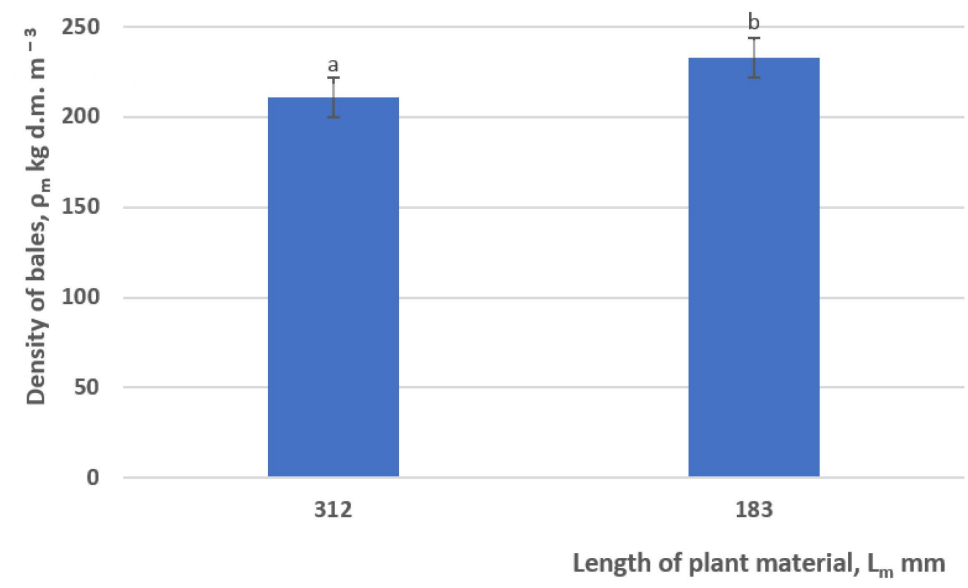

Figure 10. Bar chart of balage density in bales for two different plant material lengths (Lm) at $56 \%$ moisture content and a pressing pressure of $18 \mathrm{MPa}$. Different lowercase letters indicate a statistically significant difference at $p \leq 0.05 ;$ d.m., dry matter.

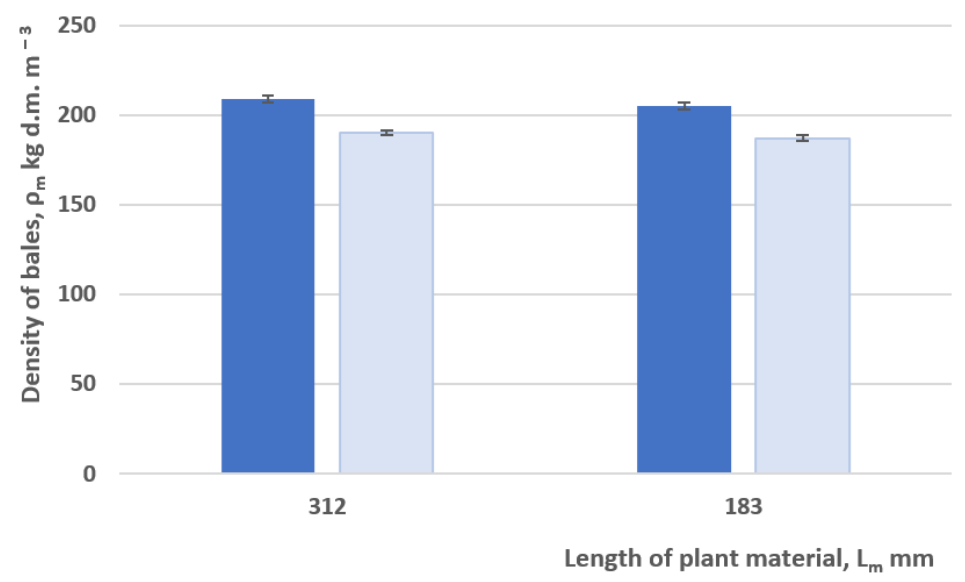

Figure 11. Bar chart of balage density in bales with additive and without additive for two plant material lengths (312 and $183 \mathrm{~mm}$ ) at 56\% moisture content and a pressing pressure of $18 \mathrm{MPa}$. d.m., dry matter.

Under the experimental conditions, the highest density values were obtained at $\mathrm{M}_{\mathrm{C}}=56 \%$. For the material being cut, the bale density was statistically different for the $\mathrm{P}_{\mathrm{P}}$ pressing pressure of 18 and $14 \mathrm{MPa}$. In each of Figures 3-8 it can be seen that the lowest bale density is for $\mathrm{Mc}=69 \%$. It is always significantly different in an experiment. The obtained test results are close to the results obtained by other studies, in which the density of cylindrical bales of forage at different moisture content levels changed across quite a wide range. Uppenkamp [11], Lenge [9], Charmley and Firth [12], and Nowak [6] reported that the highest density of balage was obtained by harvesting at a moisture content of $\sim 40$ to $50 \%$. Bales formed of forage with a higher moisture content are characterized by a low density. Forage with $\sim 40 \%$ moisture content can constitute $\sim 60 \%$ of balage density $[6,11]$.

The bar charts of the density value distributions of balage harvested at $\mathrm{M}_{C}=56 \%$ (Figure 9) indicate that $P_{P}$ has a statistically significant impact on the bales' density. Essential differences were found between the density of bales formed at $\mathrm{P}_{\mathrm{P}}=14$ and $9 \mathrm{MPa}$. In other comparisons, the differences were not statistically significant. Han et al. [4], who studied the influence of the material's pressing pressure in the working chamber of a New Holland 648 press on the basic parameters of bales of Pennisetum americanum (L.) Kostyra [22], found that the $P_{P}$ had the biggest impact on the bales' density, with a twofold increase in pressure resulting in the bales' density increasing by almost $60 \%$.

Analysis of the results also showed that the density of bales of material chopped by the cutting device of the round baler $\left(\mathrm{L}_{\mathrm{m}}=183 \mathrm{~mm}\right)$ was $\sim 10 \%$ higher than the density 
of the unchopped material $\left(\mathrm{L}_{\mathrm{m}}=312 \mathrm{~mm}\right)$ and these differences proved to be statistically significant (Figure 10).

The problem of the impact of shredding forage material on the density of bales formed by round balers has been mentioned in many studies. Most of these studies discuss the advantageous impact of including a cutting device in the collecting press on the density of the balage $[6,9,10,22]$. In these studies, depending on the experimental conditions, the results covered a wide range of densities from only a few percent to over $20 \%[6,23]$.

The data presented in Figure 11 show that differences in the bales' density with and without the additive for two different lengths of forage mix, applied in the tests $\mathrm{L}_{\mathrm{m}}=312$ and $183 \mathrm{~mm}\left(\right.$ at $\mathrm{M}_{\mathrm{C}}=56 \%$ and $\left.\mathrm{P}_{\mathrm{P}}=18 \mathrm{MPa}\right)$, did not exceed $2 \%$ and were not statistically significant. This is probably because a small increase in forage moisture content (the additive increased by $\mathrm{M}_{C}$ by $3 \%$ ) did not result in any significant changes in density.

The changes in the bales' density can be described by the equations presented in Figure 12, which are equations of the third degree. The correlation coefficient of all the equations is very high and ranges from $r=0.95$ to 0.99 . The density of the balage increased at the beginning along with a drop in moisture content (to $\sim 58 \%$ ), then decreased until reaching a minimum at $\mathrm{M}_{\mathrm{C}}=\sim 47 \%$. For both the unchopped and chopped green fodder, the density of the balage increased with the increase in $P_{P}$.

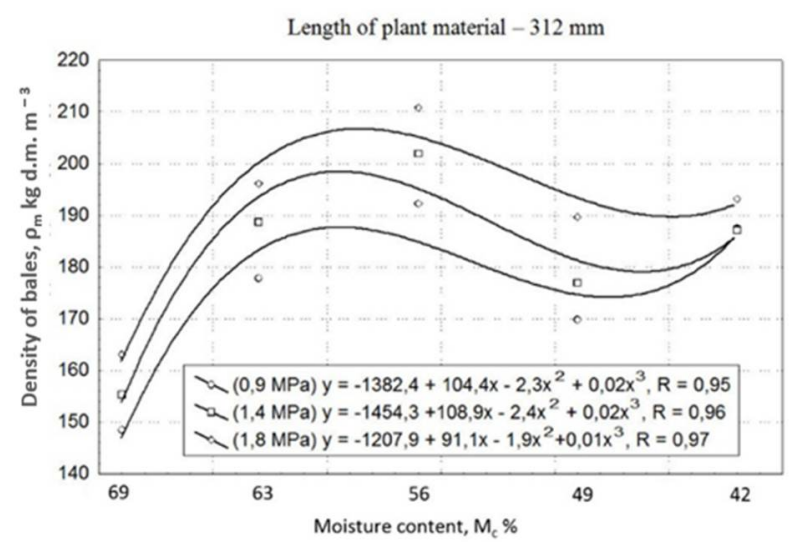

(a)

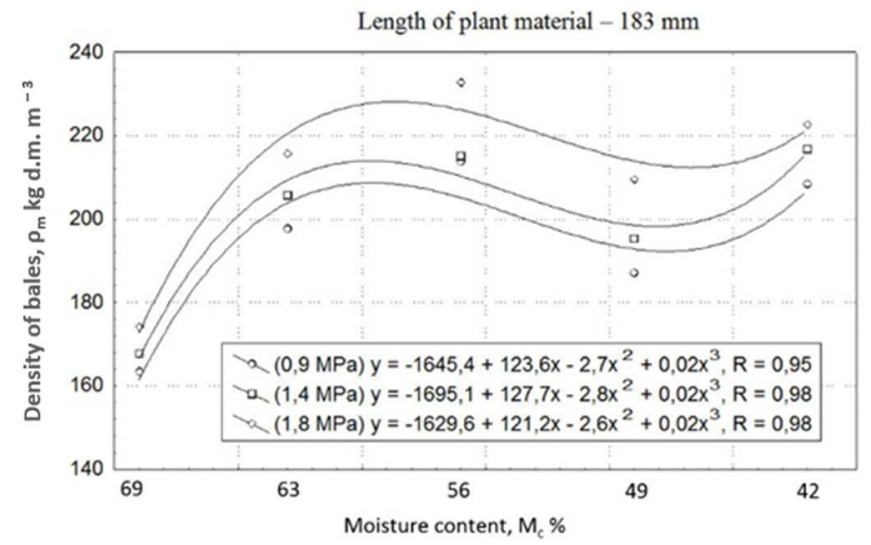

(b)

Figure 12. Relationship between balage density $\left(\rho_{\mathrm{m}}\right)$ and plant material moisture content for $(\mathbf{a})$ plant material with a length $\left(\mathrm{L}_{\mathrm{m}}\right)$ of $312 \mathrm{~mm}$ and $(\mathbf{b})$ chopped plant material at $\mathrm{L}_{\mathrm{m}}=183 \mathrm{~mm}$.

In Hersom \& Kunkle's [8] analysis of density in bales of bermudagrass (Cynodon dactylon (L.) Pers.), the results showed a moisture content range in which the maximum density 
value of the cylindrical bales was similar. Similar results were obtained in studies carried out in Germany [11].

\section{Conclusions}

Grass harvesting for haylage is a well-known issue. Based on our own experience, it can be concluded that the pressing pressure and the length of the material will directly affect the bale density. However, in the case of moisture content, care should be taken to ensure that it is correct. For the grass mixture used in the study, the best assumed moisture content was Mc $=56 \%$. Good bale density reduces transport costs and reduces the amount of oxygen in the bale. Lack of oxygen in the bale is a prerequisite for good fermentation. This situation allows the amount of chemical additives to be reduced.

On the basis of the authors' previous research, it was found that the highest quality of silage is obtained for the analyzed mixture of grasses when harvested with the addition of KemiSile 2000, using material comminution $(\mathrm{lm}=183 \mathrm{~mm})$ and a pressing pressure of $18 \mathrm{MPa}$. The humidity of the collected material should be between $49-56 \%$ [24].

Author Contributions: Conceptualization, E.D. and S.B.; methodology, E.D.; software, J.K.; formal analysis, J.K. and S.B.; investigation, J.K. and S.B.; writing-original draft preparation, E.D.; writingreview and editing, S.B.; visualization, S.B.; project administration, E.D. All authors have read and agreed to the published version of the manuscript.

Funding: This research received no external funding.

Institutional Review Board Statement: Not applicable.

Informed Consent Statement: Not applicable.

Data Availability Statement: The data presented in this study are available on request from the corresponding author.

Conflicts of Interest: The authors declare no conflict of interest.

\section{References}

1. McDonald, P.; Henderson, A.R.; Heron, S.J.E. The Biochemistry of Silage, 2nd ed.; Chalcombe Publications: Marlow, UK, 1991.

2. Müller, C.E. Fermentation patterns of small-bale silage and haylage produced as a feed for horses. Grass Forage Sci. 2005, 60, 109-118. [CrossRef]

3. Harris, P.; Ellis, A.D.; Fradinho, M.J.; Jansson, A.; Julliand, V.; Luthersson, N.; Vervuert, I. Review: Feeding conserved forage to horses: Recent advances and recommendations. Animal 2017, 11, 958-967. [CrossRef] [PubMed]

4. Han, K.J.; Collins, E.S.; Vanzant, E.S.; Dougherty, C.T. Characteristics of baled silage made from first and second harvests of wilted and severely wilted forages. Grass Forage Sci. 2006, 61, 22-31. [CrossRef]

5. Jamroz, D.; Podkówka, W.; Chachułowa, J. Animal Nutrition and Animal Feed Science; Polish Scientific Publishers: Warsaw, Poland, 2001. (In Polish)

6. Nowak, J. Machines for Forming Cylindrical Bales; Publishing House of the Univ. of Life Sciences: Lublin, Poland, 2013. (In Polish)

7. Coblentz, W.K.; Hoffman, P.C. Effects of bale moisture and bale diameter on spontaneous heating, dry matter recovery, in vitro true digestibility, and in situ disappearance kinetics of alfalfa-orchard hays. J. Dairy Sci. 2009, 92, 2853-2874. [CrossRef] [PubMed]

8. Hersom, M.; Kunkle, W. Wilting bermudagrass improves forage silage quality and cattle performance. 2003. Available online: https: / / edis.ifas.ufl.edu/an144 (accessed on 1 November 2021).

9. Lenge, R. Schneidwerk-Presse Schneidet besser ab. Top. Agrar. 1996, 3, 104-106.

10. Mumme, M.; Köhler, M. Rundballenpresse Fendt 2900 vs. Prüfbericht, 5717 F. 2007. Available online: https:/ / pruefberichte.dlg. org/filestorage/5717F.pdf (accessed on 1 November 2021).

11. Uppenkamp, N. Anwelksilage: Ein Verfahrensverglach. Auswertungs und Informationsdienst fur Ernährung, landwirschaft und Forsten; Magdeburger Druckerei Gmbh: Bonn, Germany, 1994.

12. Charmley, E.; Firth, S. Comparison of flail-harvested, precision-chopped and round-bale silages for growing beef cattle. Ir. J. Agric. Food Res. 2004, 43, 43-57.

13. Lötjönen, T. Harvest losses and bale density in reed canary grass (Phalaris arundinacea L.) spring-harvest. Asp. Appl. Biol. 2008, 90, 263-268.

14. Doroszewski, P.A. Effectiveness of Silaging Additives' Application in Preservation of Green Forages from Legume-Grass Mixture and the Whole Corn Plants; No. 136; Publishing House of the Univ. of Technology and Life Sciences: Bydgoszcz, Poland, 2009. (In Polish)

15. Dulcet, E.; Woropay, M. Analysis of liquid additives loss when applied to green forage in a forage harvester. Appl. Eng. Agric. 2000, 16, 653-656. [CrossRef] 
16. McEniry, J.; O'Kiely, P.; Clipson, N.J.W.; Forristal, P.D.; Dogle, E.M. The microbiological and chemical composition of baled and precision-chop silages on a sample of farms in County Meath. Ir. J. Agric. Food Res. 2006, 45, 73-83.

17. Muck, R. Microbiology of ensiling. In Proceedings of the XVI International Silage Conference, Hämeenling, Finland, 2-4 July 2012; MTT Agrifood Research Finland, University of Helsinki: Helsinki, Finland, 2012; pp. 75-86.

18. Weissbach, F. Prediction of biogas production potential of silage. In Proceedings of the XVth International Silage Conference, Madison, WI, USA, 27-29 July 2009; pp. 189-190.

19. Wyss, W.; Thaysen, J.; Pauly, T.; Rubenschuh, M. Testing inoculant and chemical additives in round bales in comparison to laboratory silos. In Proceedings of the XVI International Silage Conference, Hämeenling, Finland, 2-4 July 2012; MTT Agrifood Research Finland, Univ. of Helsinki: Helsinki, Finland, 2012; pp. 294-295.

20. Dulcet, E.; Kaszkowiak, J.; Borowski, S.; Mikołajczak, J. Effects of Microbiological Additive on Baled Wet Hay. Biosyst. Eng. 2006, 95, 379-384. [CrossRef]

21. Nysand, M.; Suokanns, A. Optimising the application technique for silage additive in harvesting machinery. In Proceedings of the XVI International Silage Conference, Hämeenling, Finland, 2-4 July 2012; MTT Agrifood Research Finland, University of Helsinki: Helsinki, Finland, 2012; pp. 73-74.

22. Kostyra, K. Studying of the Methods of Green Forage Harvesting in the Form of Pressed Cylindrical Bales; Production Engineering Faculty of Warsaw University of Life Sciences: Warsaw, Poland, 2001. (In Polish)

23. Schmerbauch, K.J. Gärqualität und Schimmelpil zwachstum in Silage in Abhängigkeit von Lagerungsdichte und äuBerem Luftabschluß; Institut für Nutztier Wissenschaften der Humboldt, University of Berlin: Berlin, Germany, 1999.

24. Dorszewski, P.; Dulcet, E.; Kaszkowiak, J. Influence of the round baler harvesting technique with the addition of a preservative on the quality of the obtained haylage. Bibl. Fragm. Agron. 2005, 9, 77-78. 